\title{
ÂŞIKLIK GELENEĞİ VE GELENEĞİN ÇERAĞLARINDAN AMASYALI ÂŞIK ÖZLEMÎ
}

\author{
THE MINSTRELSY TRADITION, ÂŞIK ÖZLEMÎ OF AMASYA, FROM THE \\ LIGHTS OF TRADITION
}

Şerife ÖZER ${ }^{*}$ - Mustafa TOPAL ${ }^{* *}$

\begin{abstract}
ÖZ: Âșılklık geleneği; Türk kültürünü sözlü gelenek içerisinde yaşatan en önemli unsurlardan biridir. İslamiyet öncesi devirden izler taşıyıp coğrafi, dini değişimler ve kamlık geleneğinden ozanlık geleneğine geçişle varlığını devam ettirmiştir. İslamiyet öncesi Türklerin yaşamına dayanan ve yaşanılan coğrafi bölgelere göre ozan, kam, baksı, âşık isimlerini alan zengin bir kültürel birikimin eseri olan âşıklık geleneği Orta Asya'dan Anadolu coğrafyasına uzanan ve yüzyılların sosyal kültürel coğrafi, tarihi, örf, adet ve geleneklerini yansıtan bozahaneler, kahvehaneler, çayhaneler gibi alanlarda var olmuș ve günümüze kadar gelmiștir. Halkın söylemediğini söyleyen, görmediğini gören duymadığını duyan kültürel değerleri nesilden nesle aktaran âşıklar bu gelenek içinde halkın sözcüsü ve savunucusu olmuşlardır. Yaşadığı toplumun duygu ve düşüncelerini bir potada eriterek buna tercüman olan gelenekte yüzyıllarca toplumun içinde var olan yaşadığı toplum ile bütünleșen onlarla sevinen onlarla üzülen, özleyen, seven, gurbete çıkan toplumun sözcüsü âşıklarından biri de Amasya'nın Gümüşhacıköy ilçesinde yaşamış olan Âșık Özlemî'dir. Bu çalışmada Âşık Özlemî'nin hayatı, âşıklı̆̆ı ve şiirlerinin muhteva açısından incelenmesine yer verilecektir. Âşık Özlemî yetiştiği topraklarda hayata merhaba diyen, evlenen, çalışan ayrıca kendi coğrafyasında dinleyici kitlesi oluşturarak ünlenen ünü ülkeye yayılan bir âşık olup önemli bir yere sahiptir. Özlemî'nin tanıtılması amacıyla ele alınan çalışma alanında ilk olacaktır. Âşığın gelecek kuşaklar tarafından tanınması, gelenek içindeki önemi böylece vurgulanmış olacaktır. Bundan sonra yapılacak olan bilimsel çalışmalara bu çalışmanın ışık tutacağı düşünülmektedir. Bu çalışma özellikle son dönemde ortaya çıkan konservatuar aşıklarının oluşturduğu âşıklık geleneği erozyonunu önleyecektir. Kültürel değer yargılarını ve ustaçırak ilişkisini yansıtan âşığın bilim çevrelerince tanınmasına vesile olacaktır. Böylece âşıklar külliyatının oluşmasına katkı sunacaktır.
\end{abstract}

Anahtar Kelimeler: Âşılklık, âşıklık geleneği, Amasya, Gümüşhacıköy, Âşık Özlemî

ABSTRACT: The tradition of minstrelsy; it is one of the most important elements that keep Turkish culture alive in the oral tradition. It carried traces from the pre-Islamic era and continued its existence with the transition from geographic, religious changes and the tradition of kamlik to the tradition of poetry. The tradition of minstrelsy, which is the work of a rich cultural accumulation that is based on the life of the Turks before Islam and takes the names of bard, kam, baksl, asik according to the geographical regions they live in, extends from Central

${ }^{*}$ Dr. Öğretim Üyesi - Çankırı Karatekin Üniversitesi Edebiyat Fakültesi Türk Dili ve Edebiyatı Bölümü / Çankırı - serifeozer@karatekin.edu.tr (Orcid ID: 0000-0002-1167-9317)

** Çankırı Karatekin Üniversitesi Sosyal Bilimler Enstitüsü Türk Dili ve Edebiyatı Anabilim Dalı Yüksek Lisans Öğrencisi / Çankırı - mustafatopal1309@hotmail.com (Orcid ID: 00000002-7436-6705)

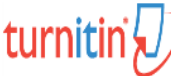

This article was checked by Turnitin. 
Asia to the Anatolian geography and reflects the social, cultural, geographical, historical, customs, customs and traditions of the centuries, It has existed in areas such as coffee houses and teahouses and has survived to the present day. The minstrels, who say what the public does not say, who see what they do not see and hear what they do not hear, have been the spokespersons and defenders of the people in this tradition. One of the spokesperson of the society, who has rejoiced, missed, loved, and went abroad, is Așlk Özlemî, who lived in Gümüşhacıköy district of Amasya. In this study, the life, minstrelsy and poems of Așıl Özlemî will be examined in terms of content. Aşı Özlemî is a lover who says hello to life in the land where it grows, gets married, works in the land where she grew up, and is also a lover whose reputation has spread throughout the country by creating an audience in her own geography. It will be the first in the field of study addressed to introduce Özlemî. Thus, the recognition of the light by future generations and its importance within the tradition will be emphasized. It is thought that this study will shed light on the future scientific studies. This study will especially prevent the erosion of the minstrelsy tradition created by the conservatory minstrels that emerged recently. Reflecting cultural value judgments and master-apprentice relationship, the lover will be recognized by scientific circles. Thus, the minstrels will contribute to the formation of the corpus.

Keywords: Minstrelsy, the tradition of minstrelsy, Amasya, Gümüşhacıköy, Âşık Özlemi.

\section{Giriş}

Âşıklık geleneği toplumun yaşamını ve sosyo-kültürel dünyasını yansıtmakta olup Anadolu'daki ozanlık geleneğinin coğrafi, kültürel ve tarihi niteliklerine göre yeniden yorumlanması ile varlığını devam ettirmiş, kuşaktan kuşağa sözlü kültür ortamının katkısı ile aktarılmıştır. "Bugün âşık edebiyatı adı ile anılan edebiyat başlangıçta ozan-baksı edebiyat geleneği olarak şekillenen ilk milli edebiyatımızın XVI. yüzyılda yeni kültür birikimi, kabuller, ihtiyaçlar, talepler, zevk ve beklentilerinin etkisi ile gelişim ve değişime uğramıș devamıdır (Günay, 1993: 22). Âşıklık geleneğinin kültürel ve sosyal kökeni birçok araştırmacının fikir birliğine vardığı araştırmalara da dayanarak İslamiyet öncesi dönem Türk edebiyatı ve kültürel coğrafyasına dayanmaktadır (Köprülü, 199: 195-238; Aslan, 2009: 17-37; Günay, 1986: 9-22). Bu edebiyat Türk kültürünün özelliklerini taşıyan yüzyıllarca süregelen kam, baksı, ozanlık geleneğinin devamı olarak karşımıza çıkmaktadır. XVI. yüzyıldan önceki dönemde yaratılmış verimler her ne ölçüde âşılk tarzına benzerse benzesin ya Tekke ya da tıpkı Dede Korkut Hikâyeleri örneğinde görüldüğü gibi İslamileşmiş bir surette devam eden ve belki bir ölçüde âşık tarzının sadece öncüsü kabul edilebilecek ozanbaksı geleneğine ait olacaktır (Çobanoğlu, 2000: 129-130). Geleneğin sözlü kültüre dayanması ve Orta Asya'dan başlayan göçlerle dini, sosyo-kültürel değişimlerin meydana gelmesi Anadolu coğrafyasında XVI. yüzyıldan itibaren görülmeye başlayan âşı edebiyatının önceki yüzyıllara ait gelişimi hakkında bilgi sahibi olmamızı zorlaştırmaktadır. Değişken ve canlı bir organizmaya özelliği gösteren âşık edebiyatına ilk adlandırmayı Fuat Köprülü yapmıştır. Köprülü geleneğin taşıyıcısı ve temsilcilerine "âşık", "saz şairi" terimlerini kullanmıştır. Bunlar, halkın telakkisine göre halk âşıklarıdır ve ilhâm kaynakları daima ilahidir (Köprülü, 1989: 165-193). XVI. yüzyılda ise değişim ve gelişimlere bağlı olarak sözlü kültürün taşıyıcısı 
âşıklık geleneği şekillenmeye başlamıştır. Ozan-baksı geleneği on altıncı yüzyıla gelince sosyo-kültürel değişimlerin etkisiyle âşık adını alarak yeni bir şekil kazanmıştır. "Âşık edebiyatının temsilcileri XVI. yüzyıla kadar ozan adını kullanırken XVII. yüzyılda bu kelime olumsuz anlamda kullanılır olmuş ve tasavvufun da etkisiyle bu edebiyatın temsilcileri arasında 'âşık' adı yaygınlaşmıştır." (Sakaoğlu, 1998: 369).

Âşıklık geleneğinin içinde yoğrulan âşık, halkın acılarını, sevinçlerini, özlemlerini, gurbet ve sıla duygusunu, kaderini yaşadığı kültürel coğrafyanın taşıdığı izlerle halkın ağız özelliklerini kullanarak yerel ve milli değerlerle toplumdan özümsediğini sanatsal yollarla topluma yansıtmayı başarmıştır. Âşıklar, yüzlerce yıldan beri zamanın şartlarına, anlayışına ve kültürel ihtiyacına göre değişim göstermiş, Türkçenin söz varlığını ve dil özelliklerini de bünyesinde taşımışlardır. Âşıklar geleneğin çerağı olmanın yanı sıra Türkçenin gelişimine katkı sağlamış günümüzde de bunu devam ettiren canlı kültür abideleridir. Toplumun değer yargılarını ve ihtiyaçlarını özümseyen âşıklar aynı zamanda yaşadığı kültürün genetik kodlarını da taşıyan kişilerdir. Âşıklık geleneği, yüzyılların deneyimlerinden süzülerek biçimlenmiş, belirli kuralları olan, şiirin kalıcı ve etkileyici özelliğinden yararlanarak kuşaktan kuşağa aktarılan bir değerler bütünüdür (Artun, 2001: 11). Türk kültürel yaşamını geleneksel özelliklerle yansıtan ayrıca âşık kollarının ortaya çıkmasına ve bu kolların devam etmesine katkı sunan deneyim ve bilgi aktarımına sahip usta ile çırak arasında köprü görevi kuran usta çırak ilişkisi âşıklık geleneğinin önemli bir özelliğidir. Çıraklık âşıklık geleneğinin okuludur. Usta çıraklar kendi sanatlarının devamını çırakları aracılığıyla gelecek kuşaklara taşırlar. Gün gelir çırak, sazın, izin, özün sırlarını, saz, söz, makam, ayak verme ve atışmayı öğrenir (Tanrıkulu, 1997: 23). Usta-çırak ilişkisinde saza ve söze yatkın olan âşık usta âşık gözetiminde geleneğin bilgi ve tecrübe aktarımına dahil olarak ustası ile diyar diyar gezer âşık meclislerine katılır ve çeşitli ortamlarda kendini göstermeye başlar. Usta âşık saza ve söze yeteneği olan bir genci çırak edinir, yanında gezdirir. Çırak ustasının ölümünden sonra meclislerde, sohbetlerde onun şiirleriyle söze başlar, adını yaşatır, izinden gider (Kaya, 1984: 40). Âşıklık geleneği toplumun değer yargılarını, duygu ve düșüncelerini bünyesinde taşıyarak halk kültürü içinde değerler bütünü oluşturmaktadır.

Amasya, sözü edilen değerler bütününü yansıtan halk âşıklarının meydana getirdiği kültürün coğrafyalarından birisidir. Halk edebiyatının kodlarını oluşturan âşıklık geleneği, Amasya'da yüzyıllar boyunca canlılığını korumuş, günümüzde de bu canlılık devam etmektedir. Amasya-Suluova'nın bir kısmı ile Merzifon ve Gümüşhacıköy Ovası'nı içine alan bölge eski dönemlerde yerli halk arasında Gaziler ovacığı olarak adlandırılmaktaydı. Gaziler ovacığı günümüzde fazlaca bilinmeyen ve kullanılmayan gayrı resmi bir yer ismidir. Kul Fakir'in bir sözünden aldığımız bu isim coğrafya olarak Amasya ile Suluova'nın bir kısmı, Merzifon Ovası ve Gümüşhacıköy'ü içine alan coğrafyayı kapsar (Akbulut, 2010: 11). Âșık Özlemî Amasya ili 
Gümüşhacıköy ilçesinde yaşamış bir halk âşığıdır. Gümüşhacıköy, Orta Karadeniz bölümünün az yüksek dağlarını kapsar. Bu dağlar arasında da Gümüş Suyu, Köseler Deresi, İmirler Deresi, Saraydüzü Deresi, Akpınar Çayı çevresinde düzlükler mevcuttur. İlçenin doğusunda ise Merzifon'a doğru uzanan, büyük bir kısmı sulanabilen verimli bir ova vardır. Bu ova aynı zamanda yörede 'Gaziler ovacığı' olarak da adlandırılır (Işık, 2003: 67-124). Alevi-Bektaşi kültürünün de yaygın olduğu "Gaziler ovacığı"nda yaşamış olan âşılar geleneğin özüne uygun yetişip usta malı ve kendi icra ettikleri eserlerle halkın özünü yansıtan sözcüleri olmuşlardır. Yüzyıllar boyunca sürüp gelen âşıklık geleneğinin ve halkın duygularının tercümanı olan Amasyalı âşıklar içinde en çok tanınanları Âşık Musa, Kul Fakir, Âşık İsa Gedik, Âşık Rıza Çulha, Ahmet Abacı, Âşı Halil İbrahim Alkaç, Âşık Engunî, Âşık Dursun, Dervişoğlu, Biçare, Sıdkî, Kul Hasan, Esrarî, Derviş Edna, Turab Ali, Caferî, Hızır Sersem, Gülamî, İskender Haki, Kul Hüseyin, Fukara Derviş, Kul Hasan, Âşık Yıldız, Âşık Veli, Fehmi Dedeoğlu, Çoban Hüseyin, Çoban Hüseyin, Abdullah Doğan, Mehmet Karagöz ve Âşık Özlemî'dir (Ankaralı, 2000).

Bu çalışmaya konu edilen Âşı Özlemî, halkın yaşamını, kültürünü ve inançlarını temsil etmiş ve bunun âşıklık geleneği içinde kuşaktan kuşağa aktarılmasında vesile olmuş halk aşığıdır. Gönül dağından diline dökülen kelimelerle kendine has icra ortamı oluşturmuş; il, ilçe ve köylerde saygınlık gören âşık toplum tarafından çok sevilmiş ve "Gaziler ovacı̆̆ı" diye bilinen Gümüşhacıköy'de yaşamıştır. Halkın acılarını, sevinçlerini, özlemlerini, gurbet, sıla hasreti duygusunu kültürel coğrafyanın taşıdığı izler ile sazı ile dile getirten Özlemî, usta çırak ilişkisi ile yetişmiş, sazı ile diyar diyar gezerek halkın, yaşadığı toplumun duygularına tercüman olmuştur.

Çalışmada Âşsı Özlemî'nin yaşamı, şiirleri ve gelenek içindeki yerine dair bilgiler verilecek, şiirleri muhteva açısından ele alınacaktır. Ayrıca dillere destan olan aşkl, sevgilisine duyduğu kavuşma arzusu ve kavuşamamanın verdiği hüzün şiirlerinden hareketle ele alınıp incelenecektir. TRT Türk Halk Müziği repertuarına giren eserleri ile bilinen halk aşığının incelenmesi ve tanıtılması geleneğin devamına ve gelenekle ilgili bir âşıklar külliyatının oluşmasına da katkı sağlayacaktır.

\section{1. Âşık Özlemî'nin Hayatı ve Âşıklığı}

\subsection{Hayatı}

Amasya'ya bağlı Gümüşhacıköy ilçesilmirler köyünde 1957 yılında dünyaya gözlerini açan Özlemî'nin asıl adı Muammer Badem'dir. Dedesi İstiklal savaşında sağ kolundan yaralanmış gazi olup köyde Çolak Hüseyin olarak bilinir. Köyde hayatını çiftçilik ile devam ettiren Çolak Hüseyin'in iki oğlu olup Âşık Özlemî büyük oğlu Çolağın Hasan'ın ikinci çocuğu olarak doğar. Ailesi Horosan'dan Tunceli ilinin Hozat ilçesine gelmiş oradan Hacı Bektaşi Dergahı'nda hizmet eden Hacım Sultan soyundan Âşık Gacim Sultan'dan devam eden Abdallar sülalesine dayanmaktadır. Bir aylıkken 
anne babası tarafından büyük dedelerine yanında hiçbir evladı kalmadığı için evlatlık verilmiş ve kendisi büyük dedesi ölene dek anne babasını tanımamıştır (Uzun, 2011: 23).

Küçük yaşlarda saza ilgisi olan Özlemî köylerine diyar diyar gezerek gelen âşıklardan etkilenir. Usta çırak geleneği içinde yetişen Özlemî'nin ilk ustaları Çorumlu halk âşıkları Âşık Borani ve Âşık Şekip Şahadoğru'dur. Özlemî'nin saza ve geleneğe olan ilgisi gün geçtikçe artmış o keman ustası da olmasına rağmen sazı seçmiştir. İlkokula başladığı yıllarda okula gelen müfettişe öğretmenini Özlemî'nin çok güzel saz çaldığından bahseder ve müfettiş onu dinler. Özlemî'nin saz çalmasından etkilenir ve cebinden iki buçuk lira çıkarıp Özlemî'ye verir. Bu olay onun saza daha da sarılmasını sağlayacaktır. Gümüşhacıköy ortaokuluna kayıt yaptıran Özlemî hem okuluna devam eder hem de dügüunlerde, özel günlerde, eş dost meclislerinde sazı sözü ile duygularını dile getirir.

Ortaokul ikinci sınıfta Bahçeli kahvehanesinde çalışır ve garsonluk yaparak para kazanır; gittiği her yere sazını götüren ve ondan hiç ayrılmayan Özlemî'nin içinde âş̧ılık ateşi yanacaktır. 0 dönemin ünlü isimlerinden Kemal Maraşlı ile arkadaş olan Mahzuni Şerif Gümüşhacıköy'e arkadaşının evine misafir olarak gelir. Kemal Maraşlı Özlemî'yi Mahzuni Şerif'in bulunduğu ortama davet eder ve iki âşık, usta ve çırak, tanışır. Kemal Maraşlı'nın vesile olduğu bu tanışma Özlemî için dönüm noktası olacaktır. Mahzuni Şerif aşığın sözünü sazını dinler ve çok beğenir. Özlemî okulu yarıda bırakıp bir buçuk sene Mahzuni Şerif ile köy köy diyar diyar gezer. Bektaşi kültüründe ve Balım Sultan sohbetlerinde saz ile dile getirdikleri duygular ile meydana çıkan Mahzuni Özlemî usta çırak ilişkisi ile Türkiye'yi dolaşır. Özlemî'nin ustası Mahzuni Şerif okuluna devam etmesi gerektiğini söyler ve Özlemî kaldığı yerden ortaokula devam eder. 1978 yılında liseye başlar. Mahzuni Şerif'ten aldığı derslerle çıraklık eğitimini tamamlamış ustalığa adım atmıştır. Davut Sulari, Âşık Hasan, Murat Çobanoğlu, Hüseyin Çırakman, Âşık Borani, Âşık Gülabi ile âşık meclislerinde yer almış, yarışmalara katılmıștır. Sonraki yıllarda Âşık Haydar Öztürk ve Hüseyin Çırakman'dan istifade etmiştir (Uzun, 2011:25).

Ustalık yaşamında ilk şiiri "Gidiyorum Suna Boylum Sen Ağlama" şiiri ile tüm yurtta ismi duyulur. Bu şiir TRT repertuarına da girmiş olup aşığın sanat hayatında da tanınmasını sağlamıștır. İlk bestesini orta okul yıllarında yapan âşık sonraki yıllarda da " Açma Yaram, Yürü yalan Dünya Senden Usandım" eserlerini yazar ve bunlar da TRT repertuarına girer.

Âşık Gümüşhacıköy Lisesinden 1978 yllında mezun olur ve girdiği üniversite sınavı sonucunda Ankara'da Basın Yayın Yüksek Okulunda okumaya hak kazanır. Bu dönem ihtilal öncesi öğrenci eylemlerinin arttı̆̆ı dönem olup Özlemî iki yıl öğrencilik hayatı yaşadıktan sonra 12 Eylül 1980 darbesinden bir gün sonra yakalanarak hapse atılır. Bunun nedeni sevgilisine yazdığı "Bir tanem" şiiridir. Şiir Devrimci Yol Gençlik Derneğinin panosunda asılı bulunur ve Özlemî tutuklanarak cezaevine girer. Yirmi sekiz 
ay mahkum olarak hapishanede kalan Özlemî buradan çıkar çıkmaz evinden alınarak asker ocağına teslim edilir. Kırklareli 109. Piyade Alayı'nda yirmi ay askerlik yapar. Askerlik bittikten sonra beş yıldır ayrı kaldığı vatanına, köyüne dönen Özlemî evlenir. Çeşitli işlerde çalışarak geçimini sağlayan Özlemî en son Gümüşhacıköy Belediyesinde işe girer ve kendini yeniden saza söze verir. 1989 'da Gümüşhacıköy ilçesinde saz çalma kursu açar ve burada yüzlerce öğrenciye saz çalmayı öğretir (Uzun, 2011: 24).

1992 yllından sonra radyo ve televizyon programlarına çıkan âşık, Sabahat Akkiraz ile tanışır ve ona "Değme Felek" şiirini seslendirmesi için verir. Tüm Türkiye'de çok sevilen şiiri Sabahat Akkiraz, Zafer Gündoğdu, Ceylan, Mustafa Uğur, Sümer Ezgü, Cengiz Özkan, Zara, Esat Kabaklı, Oğuz Aksaç, Ender Balkır, Sevcan Orhan, Emel Taşcıoğlu, Tolga Sağ gibi sanatçılar radyo ve televizyonlarda seslendirerek okurlar, aynı zamanda çeşitli televizyon dizilerinde de bu şiire yer verilmiştir.

Özlemî İstanbul Okmeydanı'nda 2 Mart 2014 tarihli trafik kazasında ağır yaralanır ve 3 Mart 2014 tarihinde gözlerini hayata kapatır. Adına her yıl anma etkinlikleri düzenlenen Âşı Özlemî'nin mezarı doğup büyüdüğü âşıklık geleneğinin filizlendiği İmirler köyündedir.

\subsection{Mahlas Alma}

Özlemî mahlas almasını şöyle anlatır: Çoğu köylü çocuğu gibi ben de çobanlık yaptım, ilk sazımı koyunlar dinledi. Her seslenişimde bana öksüz bir çocuğun bakışı gibi boyunlarını eğerek bakarlardı. Sazla kucaklaşıp dertlerimi ve özlemlerimi saza aktardım. Âşı oluşuma neden ise ana baba şefkatinden yoksun geçen çocukluğumun ana baba sevgisi ve Özlemî̀dir (Ankaralı vd. 2000: 188). Așığa Özlemî mahlasını ilk ustalarından olan Âşık Borani vermiştir. Âşık Özlemî badeli bir âşık olmayıp usta çırak ilişkisi esasında yetişmiştir.

\section{3. Özlemî'nin Şiirlerinde Muhteva}

Âșık Özlemî, Alevi geleneğine göre yetişmiş ve bu kültüre sahip âşılklar tarafından usta çırak ilişkisi ile eğitim almıştır. Âşıkların çoğunda olduğu gibi Özlemî'nin şiirlerinde de Alevi geleneği, Hz. Ali, on iki imam ve ehl-i beyt sevgisi, insan sevgisi kendini göstermektedir. Âşık Özlemî'nin şiirlerinden alınan dörtlükler ve düvazı bu bağlamda örnek olarak verilebilir. Farsçada on iki anlamına gelen düvazdeh sözcügünün kısaltılarak söylenmesi olan düvaz Alevi-Bektaşi şairlerince on iki imamı övmek, özelliklerini anlatmak amacıyla söylenen Alevi-Bektaşi gelenek yapısını ve kültürel özelliklerini yansıtan şiirlerdir. Âşık Özlemî aşağıdaki şiirde on iki imamları sırasıyla zikredip övmüş Alevi-Bektaşi inancı ile düvaz olușturmuştur. Kayıtlarda yer alan düvaz şu şekildedir.

Bağışla günahım mürüvvet sende

Medet ya Allah ya Muhammed ya Ali

Meyl-i muhabbetim sendedir sende 
Medet ya Allah ya Muhammed ya Ali

Muhammet Mustafasız hem nebisin

AliyelMurtazasin hem Velisin

Belli erenler katında nurumsun

Medet ya Allah ya Muhammed ya Ali

Hasan Hüseyindir bahr-ı ummanım

Zeynel Abidin'e yoktur günahım

İmam Bakır'dır ruh-ı revanım

Medet ya Allah ya Muhammed ya Ali

Cafer-i Sadık'ta buldum didarı

Musa'yı Kazım'dan aldım ikrarı

İmam Rıza'dır gönül padişahı

Medet ya Allah ya Muhammed ya Ali

Taki'den Naki'den ola inayet

Hasanül askeri dilimde ayet

Mehdi sahip zaman zaman mürüvvet

Medet ya Allah ya Muhammed ya Ali

Ver muradım devr-i viran aşkına

Ver muradım Şii Yezdan aşkına

Ver muradım Ali ümran aşkına

Medet ya Allah ya Muhammed ya Ali

Özlemîyem insanın esrarı sende

Cümle evliyalar seddarı sende

Doksan bin evliyanın serdarı sende

Medet ya Allah ya Muhammed ya Ali (Uzun, 2011:56).

Allah çoklukta teklik arz eden birin kendisidir, anlayışı ile Âşık Özlemî'de Kur'an ayetlerinden, Kabe'ye her şeyin insanda gizemli olduğu düşüncesi Alevi-Bektaşi geleneği ve vahdet-i vücud anlayışı ile yoğrulmuştur. Alemi yaratan tek varlığın Allah olduğunu yaratılanların ise onun yansıması ve görüntüsünden ibaret olduğunu ve ölmeden önce ölmek anlayışı ile nefsinden vazgeçtiğini de dile getirmektedir.

Ayet-i kuran insanda

Kabey-i mekân insanda

Suret-i ayan insanda 
İnsan Hak'ta Hak insanda

İnsan varlık deryasıdır

Kainatın mayasıdır

Hakikatin aynasındır

İnsan hakta hak insanda

Özlemî'yem sır veririz

İnsana secde dururuz

Ölümden evvel ölürüz

İnsan Hak'ta Hak insanda (Uzun, 2011: 68-69).

Aşağıdaki dörtlükte Hz. Ali özellikleri ile sevgi ile anlatılmaktadır, Alevi-Bektaşi geleneği ile dile getirilmektedir.

İlim deryasının kapısı Ali

Kevser ırmağının sakisi Ali

Cümle evliyanın velisi Ali

Medet Allah ya Muhammed ya Ali (Uzun, 2011: 57).

Âşık Özlemî, "Yetmiş iki millete bir nazarla bakma" anlayışı ile insanlığın barışına katkıda bulunan Hacı Bektaş-ı Veli ve Hz. Ali'den bahsetmekte yeşil el ile Hacı Bektaş-ı Veli'ye atıfta bulunmaktadır.

Kaynaşıp coştu gönlümüz

Muhabbet aşkı selimiz

Hünkara çıkar yolumuz

Gider Ali Ali diye

Böyle döner devranımız

Yeşil elde dermanımız

Şaha gider kervanımız

Gider Ali Ali diye (Uzun, 2011: 47).

Bizim şah-ı merdan Ali'miz vardır

Hünkar Hacı Bektaş Veli'miz vardır

Balım Sultan'dan dolumuz vardır

Doldur da ver içelim Ali Baba(Uzun, 2011: 54).

Âşık Özlemî'nin hayatından ve gönlünü verdiği aşkından hareketle şiirlerinin muhteva açısından ele alınması ise şöyledir:

Amasya'nın Gümüşhacıköy ilçesinde ortaokula giden Muammer aynı okuldan bir kıza sevdalanır. Okul yıllarında gelecek planları yapan âşıklar buluştukları ağacın altında birbirlerinden hiç ayrılmayacaklarına dair sözleşirler. Liseyi bitirip Ankara'da üniversite öğrencisi olan Özlemî 
geleceğe dair planlar yapar ancak feleğin gönül tellerine değdiğinden habersizdir. Sevdiğine olan aşkını dile getirdiği dörtlük şöyledir:

Gönlüm düştü güzel bir canana

Yanakları gonca bir güle benzer

Mevlam sabır versin ona yanana

Yeni çiçek açmış dala benziyor

Beni Mecnun edip saldı çöllere

Bülbül konar imiş gonca güllere

Kurban olam o şirin dillere

Daha el değmemiş güle benziyor

Gözleri aklım başımdan aldı,

Kirpikleri dertli sinemi deldi

Özlemî așkından divane oldu

Coștu deli gönlüm sele benziyor (Ankaralı, 2000: 188).

Sevdiğine yazdığı şiir onun için sonun başlangıcı olur ve 12 Eylül öncesi yazılan şiir yüzünden darbe sonrası idam ile yargılanır.

Hani bir ben var ya bir tanem, bir ben,

Karanlıklara sığınıp ağlayan,

Umutlar peşinde koşan ben,

Yaralıyım zalimin ahıyla,

Bazen dolar, bazen boșalırım,

Issız Anadolu köșelerinde

Yazgılara düşmanlığım artıyor

Haykırmak istiyorum halkıma,

Bir ben miyim susmaya mahkûm olan,

Bir ben miyim horlanan.

Sen istersen bir tanem,

Ylkılır bu düzen,

Kırılır bu çark,

Durur bu devran.

Yeter ki sen iste bir tanem, sen iste ( URL-1)

İki buçuk yll cezaevinde yatan Özlemî, idam edilmekten kurtulur ancak sevdiğini "Mahkuma kız verilmez." düşüncesi ile başkası ile evlendirirler.

Yaralıyım zalimin ahıyla

Bazen dolar bazen boşalırım

Issız Anadolu köşelerinde 
Yazgılara düşmanlığım artıyor (URL-1)

Özlemî öfkelidir, insanlara ve yaşama küskündür. O sevdiğini özler, ona hasret duyar yâri düşler, yarası derine inmiş gül yüzlü sevdiğinden ayrılmıştır. Sevdiğine olan hasreti şöyle dile getirir:

Suna boylum senden ayrı kalırsam

Perişan halimi gör benim benim

Senden başkasını seversem eğer

Lanet et yüzüme var benim benim (Uzun, 2011: 41).

Katıldığı bir televizyon programında sevdiğinin ölüm haberini alan Özlemî, sazının teline vurur ve gözyaşlarına gönlünden dökülen sözler eşlik eder. Aşkı gözlerinin önünde kor olmuş gitmiş bir âşıktır. Yollarına türlü tuzaklar kuran, onu her geçen gün yoran feleğe seslenen Özlemî, feleğe teline değmemesini söylese de felek onun gönül telini koparmış gönlüne sızı bırakmıştır ancak bunu kimse bilmez. Sevdiğine ecel oku değmiş, sevdiğinin ölüm haberi ile dilinden dökülen sözler aslında onun gönlünden dökülür ve nağmelerle tüm Türkiye'de söylenir halk tarafından sevilip benimsenir. Âşık Özlemî "Değme Felek" şiiri ile duygularını dışa vurmuştur.

Bugün benim efkârım var zarım var

Değme felek değme telime benim

Gül yüzlü cananı elden aldırdım

Ecel oku değdi gülüme benim

Değme felek değme gülüme benim

Lokman hekim gelse sarmaz yarayı

Hilebaz dostunan açtım arayı

Ne köșkümü koydu ne de sarayı

Baykuşlar tünedi dalıma benim

Değme felek değme telime benim

Özlemî'yem bașım dumanlı dağlar

Gözlerim yaşlı da içim kan ağlar

Güz ayları geldi bozuldu bağlar

Hazan yeli değdi gülüme benim

Değme felek değme gülüme benim (Uzun, 2011: 28).

Başına gelenler, yaşadıkları sevdiğine kavuşamamanın verdiği hüzün Özlemî'nin şiirlerinde vücuda gelmiştir. Artık âşık ömrünün geçip gittiğine şu dörtlükte ah eder.

Düştü başım kaldıramam ki yerden

Her taraftan geldi türlü bir sitem

Geçti ömrüm gayrı ben nasıl edem

Vay başıma gelene bak gelene (Uzun, 2011: 71). 
Dünyada felekten ok yiyen Özlemî'nin yüreği orta yerinden bölünmüştür. Artık seher yelinde öten bülbül ötmez olmuş akan çay iken durulmuştur.

Özlemî'yim gayri dostum yoruldum

Deli akar idim şimdi duruldum

Felek bir ok attı şimdi vuruldum

Vay başıma gelene bak gelene (Uzun, 2011: 71).

Âşık Özlemî'de zamanın geçiciliği ve ömrün kısa olmasını bahar ve yaz aylarına, ağızdan çıkan sözler gibi kısa olmasına, bir kuş gibi dudaktan uçmasına benzetmiştir. Sevgilinin sembolü şairlerin ilham kaynağı olduğu gibi Özlemî'de gülün açılıp solması gibi ömrün de açılıp solduğu dile getirilmiştir. Ömür çok hızlı ve boşa geçmiş âşı gönlünce bir ömür sürememiştir.

Hayal gibi düş gibi

Geçip gitti benim ömrüm

Kafesteki bir kuş gibi

Uçup gitti benim ömrüm

Sanki bahar yazlar gibi

Dalıp giden gözler gibi

Dudaktaki sözler gibi

Çıkıp gitti benim ömrüm

Uzun kısa yollar gibi

Açıp solan güller gibi

Özlemî'yim seller gibi

Akıp gitti benim ömrüm (Uzun, 2011: 58).

Âşığın bazı şiirlerinde ahlaki değerleri ele alan vefa, alçak gönüllülük gibi kavramlar üzerinde duran temalar vardır. Şiirlerinde öğreticiliği ön plana çıkaran âşık iyiyi, doğruyu güzeli anlatır. Özlemî kişiye verilen öğütten hareketle aslında topluma mesaj vermektedir. Sözlü olarak ortaya çıkan nasihat verme geleneği âşıklarda yaygın olarak ele alınan konulardan olmuştur.

Dinle beni ey Keziban bacı

Dost muhabbetinden kaçıcı olma

Yıkma dost kalbini acıdır acı

Sorma üstadından davacı olma

Uğratma yolunu cahil yoluna

Gönül verme parasına puluna

Düşürürler seni halkın diline 
Sonra ah çekip de eyvahcı olma

Bülbül eğlenmez her yeşil bağda

Duman eksik olmaz yüce dağda

Gençliğin fidandır en güzel çağda

Yoksulun suyundan içici olma

Sorsalar sana dost kurbanıyım

Gerçek dost olana can kurbanıyım

Ben Özlemî'yim halkın ozanıyım

Unutma ustanı yıkıcı olma (Uzun, 2011: 32).

\section{Sonuç}

Türk kültürünün önemli bir bölümünü teşkil eden âşılılı geleneği sözlü kültür içinde doğmuş ve günümüze dek yaşamını sürdürmüştür. Toplum hayatına ve yaşadığı toplumun duygularına tercüman olan âşıklar tarafından bu gelenek günümüzde de teknolojik gelişmelerin gölgesinde kalmasına rağmen yaşatılmaktadır. $\mathrm{Bu}$ çalışmada Amasya'nın Gümüşhacıköy ilçesinde yaşamış olan ve mütevazı bir hayat süren halk aşı̆̆ı Âşık Özlemî'nin yaşamı, aşkı, mahlas alması ve âşıklık geleneğine nasıl başladığı hakkında bilgi verilmiştir. Âşığın âşıklık geleneğindeki önemi vurgulanmıştır. Ayrıca, aşığın şiirlerinden bazıları muhteva açısından incelenip yaşadığı zorlu hayatını ve inanç yapısını yansıtan şiirlere de yer verilmiştir. Âşık Özlemî, gelenek içinde usta çırak ilişkisi ile yetişmesi ve bulunduğu toplumun sözcüsü olması yönüyle sözlü kültürün idame ettirilmesine katkıda bulunmuş; son zamanlarda dejenere olan ve yok olmaya yüz tutmuş geleneği sazı ve sözüyle yaşatmaya çalışarak geleneğin devam etmesine katkı sağlamıştır. Ayrıca âşık külliyatına katkı sunarak sözlü gelenek içinde kültürün taşıyıcısı olmuştur. Türk dilinin gelişimine katkıda bulunan, Türklerin folklor yaşamından kesitler sunan ve günümüze dek gelen âşıklık geleneğinin okyanusunda Âşık Özlemî bir katre ile hemhal olup sazı ve sözü ile bu okyanusun içinde bakî kalmıştır. Özellikle Gümüşhacıköy ilçesinde geleneği sürdüren âşıklar üzerine bilimsel incelemelerin yapılması bölge âşıklarının daha çok tanınmasına da vesile olacaktır. Geleneğin içinde yer alan Özlemî'nin Alevi geleneğine bağlı olduğu hem bu geleneğin özünü yansıttığını hem de dünyevi konularla ilgilenmiş olduğunu görülmektedir. Ayrıca çalışmada âş̧ı kavramının gelenek içinde nasıl oluştuğuna değinilmiştir. Özlemî adına ilk bilimsel çalışma bu makale olacaktır. Bu yönüyle bu alanda çalışma yapacak olanlara makalenin kaynak niteliğ taşıyacağı düşünülmektedir. Özlemî'nin usta çırak ilişkisi ile yetişmesi de geleneğin ruhunu, özünü taşıdığını ispatlar niteliktedir. Özellikle son zamanlarda konservatuar çıkışlı gelenekle bağı olmayan âşıkların kültürel ruhu taşıyamadıkları ve hazırı tükettikleri görülmektedir. $\mathrm{Bu}$ kültürel yozlaşmanın yaşandığı devirde geleneği bilen büyük ustaların 
ilgisi ile usta-çırak ilişkisi içinde yetişen Özlemî'nin gelecek kuşaklara kültürel değerlerimiz açısından aktarılması ve tanıtılması da halk kültürüne ve geleneğe katkı sunacaktır.

\section{KAYNAKÇA}

\section{Yazılı Kaynaklar}

Ankaralı, A. - Cin, S. - Tuncay, A. G. (2000). Dünden bugüne Gümüşhacıköy. Gümüşhacıköy: Ticaret ve Sanayi Odası.

Artun, E. (2001). Âşıklık geleneği ve Âşık edebiyatı. Ankara: Akçă̆

Aslan, E. (2009). Şamanizm ve şamandan âşı̆̆g intikal eden trans olgusu. Motif Akademi Halkbilimi Dergisi, 2 (3-4), 17-37.

Çobanoğlu, Ö. (2000). Âşsı tarzı kültür geleneği ve destan türü. Ankara: Akçă̆

Günay, U. (1993). Âşık tarzı şiir geleneği ve rüya motifi. Ankara: Akçağ.

Işık, C. (2013). Erenlerin süreği, Alevi dervişlik geleneği ve Derviş Ruhan. İzmir: Tibyan

Kaya, D. (1984). Âşıl İsmeti hayatı ve deyişleri. Sivas: Esnaf.

Köprülü, F. (1989). Edebiyat araştırmaları I. İstanbul: Ötüken

Sakaoğlu, S. (1998). Türk saz şiiri. Türk Dünyası El Kitabı, C.3. Ankara: Türk Kültürünü Araştırma Enstitüsü.

Tanrıkulu, N. İ. (1997). Âşıklar divanı- Günümüz âşıkları. İstanbul: Kendi.

Türkan, H.K. (2011). Âşık Kıraç Ata'nın hayatı sanatı ve şiirleri üzerine bir inceleme. Niğde: Niğde Üniversitesi, Sosyal Bilimler Enstitüsü Yayımlanmamış Yüksek Lisans Tezi.

Uzun, G. (2011). Âşsı Özlemi'nin hayatı ve eserleri. Sakarya: Sakarya Üniversitesi Devlet Konservatuarı Temel Bilimler Bölümü Yayımlanmamıș Lisans Tezi.

\section{Elektronik Kaynaklar}

URL-1: "Yeşil Gazete". https://yesilgazete.org/arada-bir-12-eylul-urunu-bir-turkuyasar-ozurkut (Erişim: 25.11.2020)

\section{EKLER}

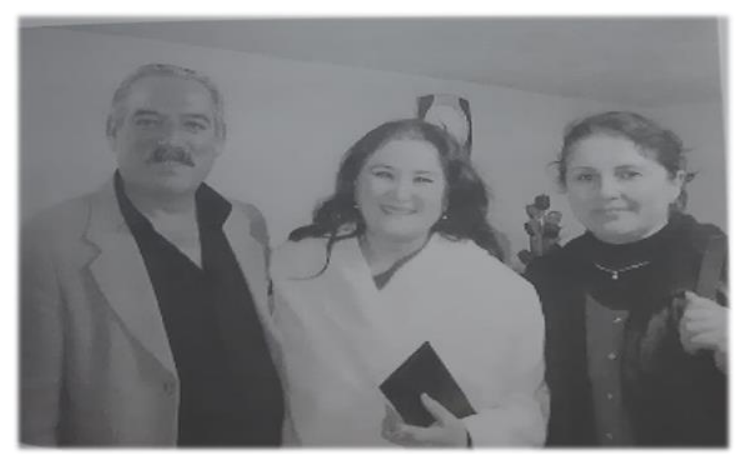

Görsel 1. Âşılk Özlemî, Sabahat Akkiraz, Eşi (Uzun, 2011:97). 


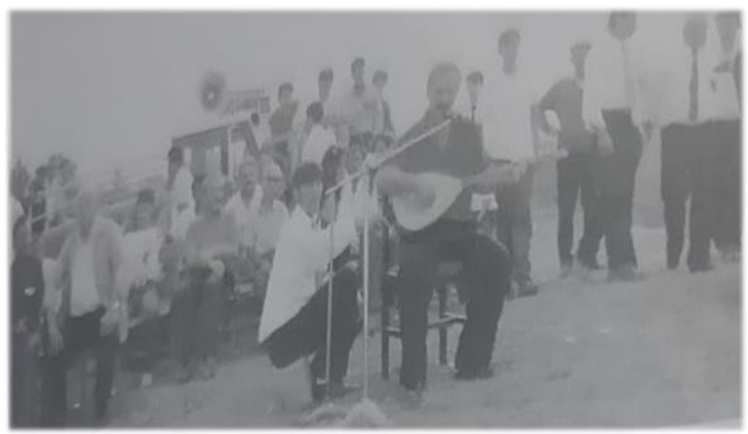

Görsel 2. Âşık Özlemî (Uzun, 2011: 95).

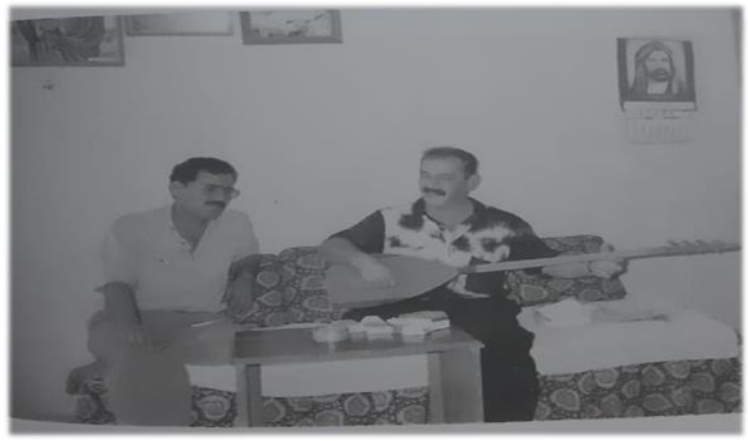

Görsel 3. Bektaş Kızılok, Âşıı Özlemî (Uzun, 2011: 96).

İyi Yayın Üzerine Kılavuzlar ve Yayın Etiği Komitesi’nin (COPE) Davranış Kuralları" çerçevesinde așağıdaki beyanlara yer verilmiștir. / The following statements are included within the framework of "Guidelines on Good Publication and the Code of Conduct of the Publication Ethics Committee (COPE)":

İzinler ve Etik Kurul Belgesi/Permissions and Ethics Committee Certificate: Makale konusu ve kapsamı etik kurul onay belgesi gerektirmemektedir. / The subject and scope of the article do not require an ethics committee approval.

Çıkar Çatışması Beyanı/Declaration of Conflicting Interests: Bu makalenin araştırması, yazarlığı veya yayınlanmasıyla ilgili olarak yazarların potansiyel bir çıkar çatışması yoktur. / There is no potential conflict of interest for the authors regarding the research, authorship or publication of this article.

Katkı Oranı Beyanı/Author Contributions: İçerik düzenleme, tanımlama ve inceleme kısımları birinci yazar tarafından gerçekleştirilmiştir. İkinci yazar makaleye konu edilen sanatçının biyografisi ile ilgili bilgileri derlemiștir. / Content editing, description and review parts were carried out by the first author. The second author compiled information about the artist's biography, which is the subject of the article. 